\title{
A note on the effect of restricted consumption of water and/or dry matter in milk replacer on growth by male and female Alpine kids
}

\author{
A.L. Goetsch, R. Puchala, M. Lachica, T. Sahlu and L.J. Dawson \\ E (Kika) de la Garza Institute for Goat Research, Langston University \\ P. O. Box 730, Langston, Oklahoma 73050, USA
}

(Received 10 December 1999; accepted 8 May 2000)

\section{ABSTRACT}

Seventy-nine Alpine kids ( 35 female and 44 male) were used to determine effects on liveweight gain of milk replacer consumed ad libitum (I) or with restricted consumption of water (II) or both water and dry matter (III). Kids began the 8-week experiment at 3 to 9 days after birth; a commercial milk replacer was fed twice daily. The 1 kids received ad libitum access to milk replacer with $14.3 \%$ dry matter; III kids received $14.3 \%$ dry matter milk replacer, with ad libitum access in week 1 and approximately 90,80 , and $70 \%$ of consumption by I kids in weeks 2,3 , and 4 to 8 , respectively; and II kids received ad libitum access to $14.3 \%$ dry matter milk replacer in week 1 , thereafter receiving a similar quantity of dry matter as I kids and limited water, with a milk replacer dry matter concentration of $15.7,17.3$, and $19.2 \%$ in weeks 2,3 , and 4 to 8 , respectively. Milk replacer dry matter intake was 183,172 , and $157 \mathrm{~g} /$ day in weeks 1 to 4 (SE 5.6) and 219, 201, and $181 \mathrm{~g} /$ day (SE 6.4) in weeks 5 to 8; water intake was 1098, 853, and $939 \mathrm{~g} /$ day (SE 32.2) in wecks 1 to 4 and 1315,911 , and $1086 \mathrm{~g} /$ day (SE 34.6) in weeks 5 to 8 for I, II, and III, respectively. Liveweight gain was lowest among treatments $(\mathrm{P}<0.07)$ for III in weeks 1 to $4(146,131$, and $118 \mathrm{~g} /$ day; SE 5.9) and 5 to 8 (137, 140, and $115 \mathrm{~g} / \mathrm{day}$, SE 7.2, for I, II, and III, respectively). However, sex influenced $(\mathrm{P}<0.05)$ treatment effects on liveweight gain in weeks 1 to 8 (female: 129,120 , and $117 \mathrm{~g} /$ day, and male: 155,151 , and $116 \mathrm{~g} /$ day for I, II, and III, respectively; SE 7.2). Milk replacer treatment did not affect liveweight gain in the subsequent 4-week period after weaning $(\mathrm{P}>0.05)$.

KEY WORDS: $\Lambda$ pine kids, milk replacer, liveweight gain 


\section{INTRODUCTION}

A concern of many goat producers is feeding management in the first few months of life for kids removed from does soon after birth. Dairy goats are typically not allowed to nurse kids to prevent transfer of potential diseases such as caprine arthritis encephalitis (Lu and Potchoiba, 1988), in addition to use of milk for human consumption. Also, suboptimal mothering ability of and or milk production by high fibre- and meat-producing goats can result in orphan kids, often twins and triplets (Sahlu et al., 1992). Current management systems do not facilitate rapid transition at weaning from milk replacer or milk to dry feed. In some instances, milk replacer is offered at relatively high levels (e.g., ad libiium) for much of the pre-weaning period, which may retard kid interest in and consumption of dry feeds. This could result from the physical filling effect of milk or milk replacer, primarily relating to milk volume, and also to energy and nutrients bcing supplied. Hence, development of management systems for milk or milk replacer that promote a quick transition to dry feeds are of considerable interest. Furthermore, because of differences in growth potential, such feeding practices might differ between female and male kids.

Objectives of this experiment were to determine effects of restricted consumption of water and/or dry matter in milk replacer on growth of male and female Alpine kids.

\section{MATERIAL AND METHODS}

Seventy-nine Alpine kids ( 35 female and 44 male) were used. Kids began the 8 -week experiment at 3 to 9 days after birth $(3.5 \pm 0.11$ and $3.9 \pm 0.08 \mathrm{~kg}$ initial body weight for females and males, respectively). Kids were removed from dams immediately after birth and received colostrum and other normal management practices. A commercial milk replacer for sheep and goats (Lamnurs ${ }^{\mathrm{k}}$; Evergreeen Mills Inc., Ada. OK, USA) was used, with meals at 0800 and $1600 \mathrm{~h}$. The guaranteed analysis of the milk replacer was at least $23 \%$ crude protein and $30 \%$ fat (air-dry basis); dried whey and whey protein concentrate were major crude protein sources and fat arose from vegetable and animal fats. The analyzed concentration of crude protein was $24.9 \%$ dry matter.

Kids were allocated to treatments randomly, individually residing in $91 \times 91 \mathrm{~cm}$ pens. The threc milk replacer treatments were ad libitum consumption (I), restricted consumption of water alone (II), and restricted consumption of both water and dry matter (III). The manufacturer's mixing recommendation for goat kids was a mixture containing $15.25 \%$ of the dry milk replacer (air-dry basis), and with an analyzed dry matter concentration in the dry milk replacer of $94 \%$, the 
recommended final dry matter concentration was $14.3 \%$. Thus, I kids received ad libitum access to milk replacer reconstituted to $14.3 \%$ dry matter. The III kids received $14.3 \%$ dry matter milk replacer, with ad libitum access in week 1 and approximately 90,80 , and $70 \%$ of consumption by I kids in weeks 2,3 , and 4 to 8 , respectively. The II kids received ad libitum access to milk replacer reconstituted to $14.3 \%$ dry matter in week 1 , thereafter receiving a similar quantity of dry matter as I kids and limited water, with a milk replacer dry matter concentration of $15.7,17.3$, and $19.2 \%$ in weeks 2,3 , and 4 to 8 , respectivcly. Kids received free access to water after 1 week on the experiment, and starter diets based on different cereal grains (i.e., maize, oats, maize-oats mixture) were given free-choice after week 1 as well. Starter dicts ranged from 23.2 to $24.8 \%$ crude protein and 14.3 to $23.4 \%$ neutral detergent fibre (DM basis). Starter diet consumption was negligible in the first few weeks; type of starter diet did not affect performance and, thus, was not considered in the final statistical analyses.

The milk replacer feeding period lasted 8 weeks. Thereafter, kids were abruptly weaned, with consumption of only starter diet for an additional 4 weeks. Kids were weighed at birth, at the start of the experiment, and every 28 days thereafter. Blood samples were collected from females by jugular venipuncture after 4 and 8 wecks, just before the morning meal and at $6 \mathrm{~h}$ later. Plasma, harvested by centrifugation at $1500 \mathrm{xg}$ for $15 \mathrm{~min}$ at $4^{\circ} \mathrm{C}$, was analyzed for urea (Chaney and Marbach, 1962) and glucose (Technicon Instruments Co., Tarrytown, NY, USA). Milk replacer and starter diets were sampled weekly, milk replacer was analyzed for dry matter and nitrogen (AOAC, 1990), and starter diets were analyzed for dry matter, nitrogen, and neutral detergent fibre (filter bag technique; ANKOM Tecnology Corp., Fairport, NY, USA).

Data were statistically analyzed as a completely randomized design by General Linear Models procedures of SAS (1990). The model for milk replacer intake and livewcight gain consisted of milk replacer treatment, sex, and their interaction. Blood urea and glucose concentrations for female kids were analyzed as a split-split-plot, with a main plot of milk replacer treatment, sub-plot of week, and sub-sub-plot of time. When interactions existed $(\mathrm{P}<0.05)$, data were analyzed by week and or time. Differences among means were determined by least significant difference procedures with a protected $\mathrm{F}$-test $(\mathrm{P}<0.05)$.

\section{RESULTS}

Intakes of milk replacer dry matter plus water, dry matter, and water were fairly similar to those intended (Table 1). For example, dry matter intake was similar ( $P>0.05)$ between I and II in weeks 1 to 4,5 to 8 , and 1 to 8 and was lowest among treatments $(\mathrm{P}<0.05)$ for III in weeks 5 to 8 and 1 to 8 . However, 
TABLE

Effects of restricted consumption of water and/or dry matter in milk replacer on milk replacer intake, liveweight gain, and blood constituent concentrations in female and male Alpine kids

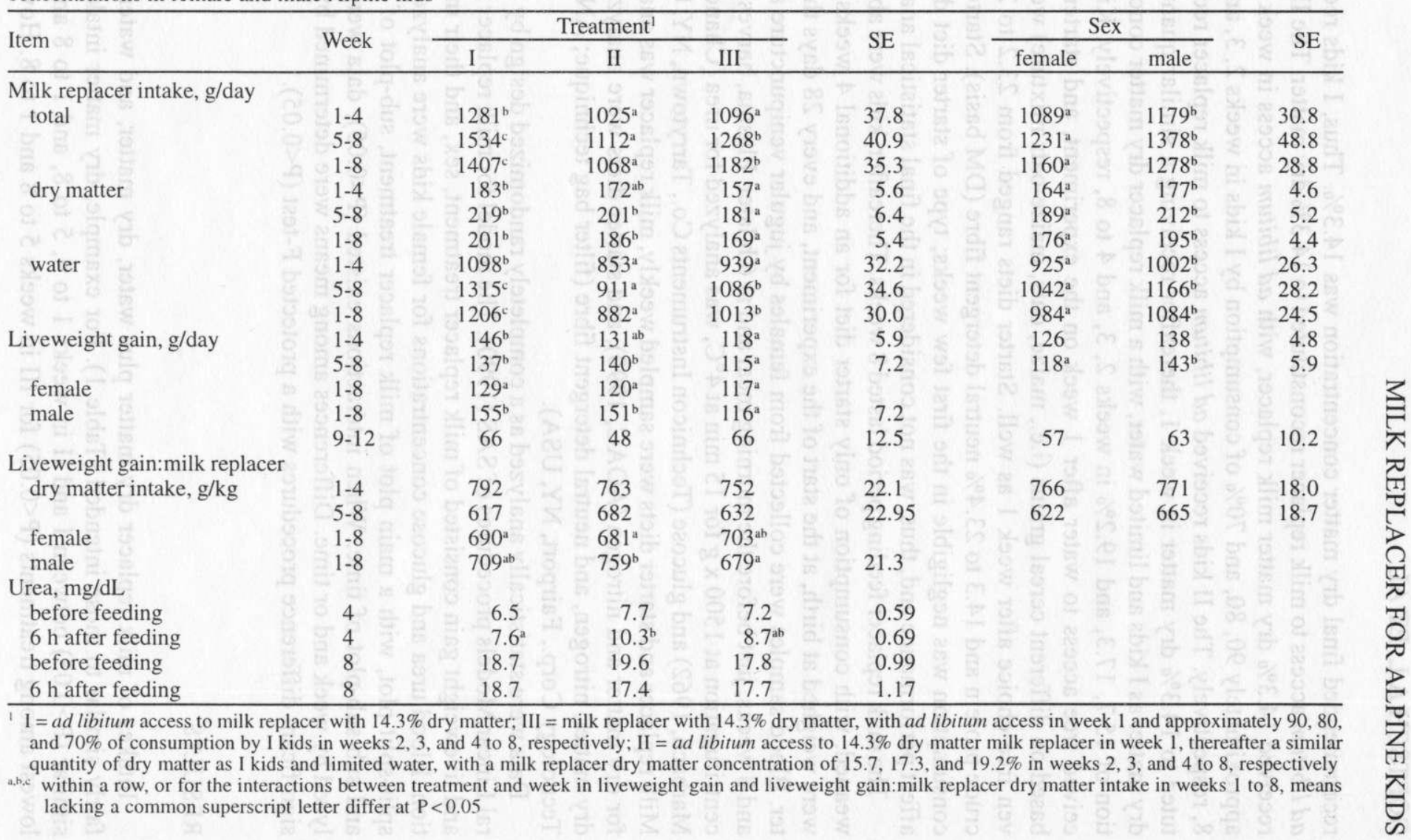


water intake differed $(\mathrm{P}<0.05)$ between II and III in weeks 5 to 8 and 1 to 8 , although water intake was greatest among treatments $(P<0.05)$ for I and the difference between II and III was much less than that between I and II.

Milk replacer treatment and sex did not interact $(\mathrm{P}>0.05)$ in liveweight gain in weeks 1 to 4 and 5 to 8 ; however, overall in weeks 1 to 8 effects of milk replacer treatment on liveweight gain differed between females and males (interaction, $\mathrm{P}=0.05$; Table 1$)$. Liveweight gain was greatest $(\mathrm{P}<0.05)$ for I vs III and lower $(\mathrm{P}<0.05)$ for III vs II in weeks 1 to 4 and lowest among treatments $(\mathrm{P}<0.05)$ for III in wecks 5 to 8 . Scx did not affect liveweight gain in weeks 1 to $4(\mathrm{P}>0.05)$, but liveweight gain was $25 \mathrm{~g} /$ day greater $(\mathrm{P}<0.05)$ for males than for females in wecks 5 to 8 . For the entire 8 -week milk replacer feeding period, milk replacer treatment did not affect liveweight gain of females, whercas for males liveweight gain for III was lowest among treatments $(\mathrm{P}<0.05)$. The ratio of liveweight gain to milk replacer dry matter intake varied with dietary treatment and sex in a manner similar to that for liveweight gain. Liveweight gain in the 4week post-weaning period was much lower than earlier and not affected by milk replacer treatment or sex $(\mathrm{P}>0.05)$.

Plasma urea concentration in females was affected $(\mathrm{P}<0.05)$ by a three-way interaction of milk replacer treatment, week, and time and, hence, was analyzed by week and time (Table 1). The only effect of milk replacer treatment on plasma urea concentration was at 4 weeks and $6 \mathrm{~h}$ after the morning meal, with the level being greater $(\mathrm{P}<0.05)$ for II vs I. Glucose concentration was similar among treatments $(\mathrm{P}>0.05)$.

\section{DISCUSSION}

One of the postulates of this experiment was that restricting intake of milk replacer water and/or dry matter would improve liveweight gain of kids after weaning by increasing starter diet consumption. Based on observed liveweight gain after weaning, it does not appear that restricted intake of water and/or dry matter had this effect. Presumably the low level of dry matter intake restriction relative to that in other experiments (Sanz Sampelayo et al., 1987, 1988, 1990) was of insufficient magnitude to markedly increase dry feed consumption. No differences among milk replacer treatments in post-weaning liveweight gain and slow growth relative to that during the 8 -week milk replacer feeding period suggest that kids on all treatments were not well conditioned for the abrupt weaning imposed. Although, reductions in liveweight gain of this magnitude in the immediate post-weaning period are common (Sanz Sampclayo et al., 1987) and a significant industry challenge. 
Similar liveweight gain for I and II kids indicates that the degree of water intake restriction for II was less than necessary to cause digestion disturbances and limited intakes due to high osmolarity of the reconstituted milk replacer. The degree to which fluid or water intake restricts milk replacer dry matter intake was not tested in this experiment. But, based on similar liveweight gain by I and II kids water ingested with milk replacer did not seem to impact starter diet intake. Lowest weight gain for III in weeks 1 to 4 and 5 to 8 implies that starter diet consumption by these kids was not compensatory for the restricted milk replacer dry matter intake. Pcrhaps other diets or feedstuffs might have been consumed more readily. In addition, greater social and fecding interactions than possible with the individual pen system employed might have yielded different results as well.

The liveweight gains are similar to those with milk replacer or goat milk reported by Sanz Sampelayo et al. $(1987,1988,1990)$. As expected, in the present experiment milk replacer intake and liveweight gain in weeks 1 to 4 and 5 to 8 were greater for males than for females. Apparently, the greater growth potential of males vs females allowed an effect on liveweight gain of restricted milk replacer dry matter intake for III, whereas the level of nutrient restriction was insufficient to limit growth of femalc kids.

\section{CONCLUSIONS}

Restricting intake of water alone in milk replacer did not enhance liveweight gain of Alpine kids, and lower growth potential of female vs male kids may lessen susceptibility to effects of limited milk replacer dry matter intake.

\section{REFERENCES}

AO^C, 1990. Official Methods of Analysis. 14th Edition. Association of Official Analytical Chemists, Washington, DC

Chaney A.L., Marbach E.P., 1962. Modified reagent for determination of urea and ammonia. Clin. Chem. 8, 130-132

Lu C.D., Potchoiba M.J., 1988. Milk feeding and weaning of goat kids - a review. Small Ruminant Res. $1,105-112$

Sahlu T., Carneiro H., El Shaer H.M., Fernandez J.M., 1992. Production performance and physiological responses of Angora goat kids fed acidified milk replacer. J. Dairy Sci. 75, 1643-1650

SAS, 1990. SAS/STAT User's Guide (Version 6, 4th Edition, Volume 2). SAS Institute Inc., Cary, $\mathrm{NC}$

Sanz Sampelayo M.R., Muñoz F.J., Guerrero J.E., Gil Extremera F., Boza J., 1988. Energy metabolism of the Granadina breed goat kid. Use of goat milk and a milk replacer. Anim. Physiol. Anim. Nutr. 59, 1-9 
Sanz Sampelayo M.R.. Muñoz F.J., Lara L., Gil Extremera F., Boza J., 1987. Factors affecting preand post-weaning growth and body composition in kid goats of the Granadina breed. Anim Prod. 45, 233-238

Sanz Sampclayo M.R., Ruiz I., Gil F., Boza J., 1990. Body composition of goat kids during suckling. Voluntary feed intake. Brit. J. Nutr. 64.611-617

\section{STRESZCZENIE}

\section{Wplyw ograniczenia pobierania wody i/lub suchej masy z preparatu mlekozastępczego na wzrost koziolków i kózek rasy Alpine}

Ośmiotygodniowe doświadczenie przeprowadzono na siedemdziesięciu dziewięciu koźlętach rasy Alpine ( 35 kózek i 44 koziołki) celem określenia wpływu pobierania do woli preparatu mlekozastępczego (grupa I), ograniczonego pobierania wody (grupa II) lub ograniczonego pobierania wody $i$ suchej masy (III) na przyrosty. Koźlęta włączano do doświadczenia od 3 do 9 dnia po urodzeniu. Handlowy preparat mlekozastępczy podawano dwa razy dziennie. Koźlęta grupy I otrzymywały preparat mlekozastępczy (PM) (14,3\% s.m.) do woli, grupy III - PM (14,3\% s.m.) do woli w pierwszym tygodniu i następnie 90,80 i 70\% ilości pobieranej przez koźlęta grupy I w 2, 3 oraz 4-8 tygodniu, odpowiednio. Koźlęta grupy II otrzymały PM (14,3\% s.m.) do woli w pierwszym tygodniu, potem podobną ilość s.m. jak koźlęta grupy I i ograniczoną ilość wody, tak że zawartość s.m. w PM wynosiła 15,$7 ; 17,3$ i $19,2 \%$ w tygodniu 2,3 oraz 4 do 8 , odpowiednio.

Pobranie s.m. z PM wynosiło 183, 172 i 157 g/dzien (SE 5,6) w tygodniach 1 do 4 oraz 219, 20 ! i $181 \mathrm{~g} /$ dzień (SE 6,4) w tygodniach 5-8; pobranie wody wynosiło 1098.853 i $939 \mathrm{~g} /$ dzień (SE 32.2) w tygodniach 1 do 4 oraz 1315,911 i 1086 g/dzień (SE 34,6) w tygodniach 5 do 8, w gnipach I. II i III, odpowiednio. Przyrosty m.c. koźląt różniły się między grupami $(\mathrm{P}<0,07)$ i były najniższe $\mathrm{w}$ grupie III w tygodniach 1 do 4 (146, 131 i $118 \mathrm{~g} /$ dzień; SE 5,9) oraz 5 do $8(137,140 \mathrm{i} 115 \mathrm{~g} / \mathrm{dzien}$; SE 7,2, w grupach I, II, III, odpowiednio). Przyrosty były zależne od płci $(\mathrm{P}<0,05)$, od I do 8 tygođnia (kózki: 129, 120 i 117 g/dzień i koziołki: 155, 151 i 116 g/dzień, w grupach I, II i III, odpowiednio; SE 7,2). Sposób podawania PM nie miał wpływu na przyrosty w ciągu 4 tygodni po odsadzeniu $(\mathrm{P}>0,05)$. 